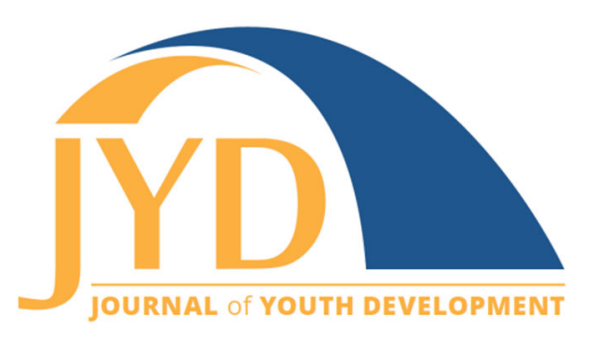

http://jyd.pitt.edu/ | Vol. 15 Issue 5 DOI 10.5195/jyd.2020.785 | ISSN 2325-4017 (online)

\title{
Leading With Youth of Color: Organizing for Educational Change
}

\author{
Rachael Lee Ficke Clemons \\ Rhode Island College \\ rclemons@ric.edu
}

\begin{abstract}
In the United States, young people of color are under attack. The school-to-prison pipeline, poverty, and racism are some of the systems of oppression that young people of color navigate. The challenging conditions that youth of color face have historically been met by their powerful resistance. Young people of color have fought for educational equity for decades. In the community in which this research study was situated, social justice youth development (SJYD) workers supported youth as they resisted unjust educational policies. I set out to answer the research question: In urban communities, how do youth workers engage adolescent youth in social justice activism? I found that adult youth workers at People for Change, a SJYD organization, maintained a consistent and multi-layered approach to supporting youth as they engaged in social justice activism. This paper highlights the ways in which adult youth workers (a) networked adult and youth supporters, (b) engaged in action, and (c) co-constructed knowledge with young people of color.
\end{abstract}

Key words: social justice youth development, youth organizing, youth worker

\section{Introduction}

In the United States, young people of color are under attack. The school-to-prison pipeline, poverty, and racism are some of the systems of oppression that young people of color navigate (Anyon, 2014; Dialogic \& Critical Pedagogies, 2017; Ginwright \& Cammarota, 2002). The challenging conditions that youth of color face have historically been met by their powerful resistance. For example, in 1951, Barbara Johns, a 16-year-old student at Robert Russa Motan High School in Virginia organized young people at her school to strike in protest of poor conditions at their school. Later, Johns' organizing work turned into a legal case to fight for the

(cc) EY New articles in this journal are licensed under a Creative Commons Attribution 4.0 License. This journal is published by the University Library System, University of Pittsburgh and is cosponsored by the University of Pittsburgh Press. The Journal of Youth Development is the official peer-reviewed publication of the National Association of Extension 4-H Youth Development Professionals and the National AfterSchool Association. 
desegregation of schools that was included in the 1954 Supreme Court ruling, Brown v. Board of Education (Wormser, 2002).

In the community in which this research study was situated, social justice youth development (SJYD) workers supported youth of color as they resisted educational policies that negatively impacted them. I set out to answer the research question: In urban communities, how do youth workers engage adolescent youth in social justice activism? Activism is defined as, "taking action to effect social change" (Permanent Culture Now, 2018, p.1). Across organizational artifacts like the mission statement, social media profiles, organization promotional materials, interviews with participants, and observational data, I found that adult youth workers at People for Change maintained a consistent and multi-layered approach to supporting youth as they engaged in social justice activism. This paper highlights the ways in which study participants (a) networked adult and youth supporters, (b) engaged in action, and (c) co-constructed knowledge with young people of color.

\section{Review of the Literature}

Throughout the United States, youth of color organize to challenge systems of oppression (Anyon, 2014); however, skills and knowledge of resistance are rarely taught in traditional school settings. For example, Ira Shor argued that traditional schooling systems do not often support youth to develop the knowledge and skills they need to question dominant narratives that are published in textbooks, or to challenge unequal power relations (Dialogic \& Critical Pedagogies, 2017). Instead, traditional schooling often includes (a) banking methods of education that position young people as receptacles of knowledge (Freire, 2010), (b) inequitable disparities in the way in which schooling is engaged for young people from different socioeconomic statuses (Anyon, 2014), and (c) power dynamics that position adult teachers in power (U.S. Department of Education, 2016).

In contrast with traditional schooling models, dominant norms of schooling are challenged through SJYD. SJYD spaces provide opportunities for young people of color to develop critical consciousness and engage in action, two skills that are often lacking in traditional school settings, and in particular, school settings that primarily serve young people of color who navigate poverty (Dialogic \& Critical Pedagogies, 2017, Anyon, 2014). Ginwright and Cammarota (2002) suggest that the SJYD model provides a new lens to critique past and 


\section{Leading With Youth of Color}

present social problems, and more specifically it, "examines how youth contest, challenge, respond to, and negotiate the use and misuse of power in their lives" (Ginwright \& James, 2002 , p. 35). Through investigating society, its problems, and its systems and structures, young people of color, alongside adult allies, work to understand and change themselves and their communities (Ginwright \& Cammarota, 2002; Ginwright \& James, 2002; Ginwright, 2006). McDaniel (2017) summarized the components of the SJYD model as (a) exploring identity to understand and think critically about systems of oppression, (b) creating unity among differences, and (c) working together (adults and young people) "to take action towards dismantling systems of oppression" (p.145).

To connect and to build upon existing SJYD research, the literature surrounding SJYD practices was explored. Researchers suggest that SJYD organizations made positive impacts on the lives of young people of color from urban areas, and SJYD programs provide opportunities for youth to work towards fairness and justice in their communities (Ho et al., 2015; Kirshner, 2005). One area that is emerging in the SJYD literature is the role of adults within youth efforts to make change in their communities. Some studies focus on the importance of engaging in youth organizing and advocacy work with adult allies (Erbstein, 2013), examining the relationships of power between young people and adults (Christens \& Kirshner, 2011; Jones, 2006), and recognizing the complex roles and principles youth workers can adopt (Richards-Schuster \& Timmermans, 2017). For example, Campbell and Erbstein (2012) identified principles that adults can engage when supporting youth as they participate in changing their communities:

- "A strategic focus: getting the questions right" (p. 73): Identifying who, why and how adults will engage young people in community change.

- "Creating structures that integrate youth and adults in joint decision making" (p. 74): These structures go beyond collecting youth opinions; instead, they included opportunities for youth to think critically and be part of making community change objectives.

- "Mobilizing leaders with broad-based skills and networks" (p. 75): Networks included people with complimentary skill sets that included knowledge of youth development, strategies of youth engagement, and community organizing.

The literature surrounding youth workers informed this study by highlighting the landscape of how SJYD is being discussed and the roles of adults in SJYD spaces. Despite this growing field of literature, few studies specifically isolate the experiences of urban youth workers or highlight ways in which youth workers engage with young people of color in social justice activism 


\section{Leading With Youth of Color}

(Richards-Schuster \& Timmermans, 2017). My research study features the experience of urban youth workers, which will add to the emerging literature in this area. This study was framed around the research question: In urban communities, how do youth development workers engage adolescent youth in social justice activism?

\section{Methodology: Qualitative Sampling, Data Collection, and Analysis}

\section{Sampling}

For the qualitative sample, purposeful sampling was used to identify participants (Bogdan \& Biklan, 1992; Maxwell, 2013). Youth workers at one organization who engaged adolescent youth of color in social justice activism were invited to participate in the study. Three sampling phases were utilized to identify an organization and study participants for my research study: (a) community selection, (b) site selection and (c) participant selection.

One urban center in the United States was identified as the community for the research study. The urban community was identified first by pinpointing the cities in the state and then comparing the free and reduced-priced lunch statistics from each city to determine which urban community would be the focus of the study. Free and reduced-priced lunch is a common metric used to identify people who are navigating poverty (Anyon, 2014), and the city with the highest need for free and reduced-priced lunch was selected for this study. Specifically, $79 \%$ of the youth that attended public schools in the city qualified for free or reduced-priced lunch (Rhode Island Education Data Reporting, 2016).

Next, city-wide demographic data from the community in which the research study was situated were reviewed. The data suggested that young people of color who navigated poverty had inequitable educational opportunities. Some of the inequitable opportunities included attending school with teachers who were less experienced or taught outside their areas of expertise, and lower graduation rates (Rhode Island Education Data Reporting, 2016). The data also suggested that youth of color who were navigating poverty often faced additional challenges of housing and food insecurity, being more frequently disciplined in school, and having fewer opportunities overall (Rhode Island Education Data Reporting, 2016).

Following community selection, purposive sampling was used to select a non-profit organization that was dedicated to supporting young people of color as they worked to change their community. A range of organizations were reviewed by reading current news to learn which 
non-profit organizations had participated in social justice activism and reviewing the online profiles of the non-profit organizations that worked to engage young people of color in social justice activism (Bogdan \& Biklen, 1992). The organization, People for Change (PFC), was chosen as a research site because it was an organizing collective that supported young people of color in their work uniting youth voice and power to fight for educational policy change. Starting in 2010, they officially became a non-profit in 2016. Their mission was to build youth power so young people of color could improve educational systems that directly impacted their own lives.

Finally, participants were selected by making a direct connection with the organization. During the first meeting with potential study participants, they were invited to participate in the study. After providing consent, study participants completed a questionnaire where they disclosed their names, race, gender, and years of experience in youth work; we then made a schedule of observations and interviews. At the time, there were three adult youth workers employed at the organization, and all three consented to participate in the study. As I became connected with the community and the organization, my subjectivity and my role as a researcher became clearer to me. In the next section, I describe my subjectivity and role as a researcher, followed by the sections that describe data collection, and data analysis.

\section{Researcher Subjectivity}

I claim many identities which include being a woman, a mother, a partner, a member of a privileged socioeconomic status, and a researcher who is White. My lived experiences have led me to question and to challenge systematic oppression, and in the process of discovering more about the ways in which society operates, I have worked, and continue to work, to understand my identity and my role in working toward change.

In particular, I often reflect on how being a researcher who is White relates to my engagement in social justice activism and my research of social justice activism in urban communities. Throughout my research journey, as a person who had different lived experiences and identities as my participants, I learned with and from study participants. I was conscious of my use of self and of taking up space with my voice and body. I also constantly reflected on my intentions and actions through personal memoing. 


\section{Researcher Role}

My role as a researcher was to collect and analyze data as an observer. Before I began my study, it was reviewed by the institutional review board (IRB), and I met with potential participants to disclose all aspects of my project, including ethical concerns before they decided to participate in my study (Patton, 2002). After study participants agreed to participate in my study, I worked to gain trust with them and to become integrated in their organizational landscape as much as possible. I approached data collection as a learner, and recorded study participants' ideas and opinions (Bogdan \& Biklen, 1992).

Furthermore, I was conscious of my subjectivity and my tendency to identify with the youth worker role by being intentional about how I represented myself during data collection. For example, I built relationships with study participants by being my authentic self, by working around their schedules, by bringing food to our interviews, and by taking a genuine interest in learning more about them and their work.

\section{Data Collection}

Individual interviews of each study participant; observations of study participants in the context of their youth organizations and public community protests; and organizational artifacts, such as, promotional materials and information from organization websites were collected.

Individual semi-structured interviews using open-ended interview probes were conducted at PFC. Open-ended interview probes provide a personal approach to interviewing. Different types of interview questions were utilized including opinion and values questions to understand the values of participants, background and demographic questions to understand the background of study participants, and knowledge questions to understand the ways in which study participants described their work (Patton, 2002).

After each interview, study participants were observed working for approximately $1 \frac{1 / 2}{2}$ hours each. During the observations, descriptive and reflective field notes were recorded about the interactions between study participants and youth, context, and the activities that occurred during the time of my observations (Bogdan \& Biklen, 1992). Finally, each study participant was interviewed a second time to answer follow-up questions about the observation, and to answer additional questions about their work with youth, including information about their responsibilities at work and how they view their role and work with youth. Throughout the 
process of data collection, observations were also made at protests, at the organization, and at one school satellite site.

\section{Data Analysis}

Qualitative data were first prepared and organized in electronic folders marked with pseudonyms on a password-protected computer and in the NVIVO software program. Data were then read to reflect on the overall meaning.

Next, a detailed coding process began using NVIVO software. The NVIVO program was used as a data warehouse, but the electronic coding process that it offers was not engaged. Data were read to identify emergent codes. This process is often referred to as open coding (Bogdan \& Biklen, 1992). Each transcript was read, annotated, and reflected upon to form categories of data, or codes. Each code was supported with data from interviews and observations (Bogdan \& Biklen, 1992). This process was recursive; each transcript was analyzed for approximately thirty different codes that emerged from annotations and subsequent coding.

After coding was completed, themes in the data that related to how study participants engaged young people in social justice activism were identified. As themes were identified, data were interpreted and a series of memos was produced (Maxwell, 2013). Study participants were engaged in the process of respondent member checking of sections of the document to ensure that valid profiles of the organization and their youth work practices were created (Guba \& Lincoln, 1994). My conversations with study participants during this phase of the research process informed revisions to my report. The entire process of collecting, coding, analyzing and writing took approximately 20 months.

\section{Findings: People for Change (PFC)}

\section{Participant Introduction}

Nora, Jean, and Dylan (all pseudonyms), the adult youth workers who were study participants, claimed different identities and had different types of experience organizing for social justice causes in the community:

- Nora, an organizer at PFC with 2 years of experience, identified as a multi-lingual White woman. She grew up outside of the United States. During the time of data collection, 


\section{Leading With Youth of Color}

Nora was actively involved in an immigrant rights group that worked to support the civil rights of immigrants.

- Jean, who identified as a person of color and gender nonconforming, engaged in community organizing and established programs for people who identify as part of the LGBTQI community. They had 3 years of experience working as an organizer at PFC.

- Dylan who founded the organization and was the Executive Director, identified as a White male. Outside of his work at PFC Dylan was involved with organizing within city and state politics.

\section{Context}

In the community in which data were collected, study participants named food and housing insecurity, lack of transportation, and inequities in the education system as some of the conditions youth of color faced. In particular, study participants identified tension at school as one challenge that young people maneuvered. Often the structure and the expectations of school hindered progress and stifled youth voice. Participants came to their work with the belief that youth of color are capable of making change on their own; however, with adult support, the platform of youth voice and youth power could be expanded. Jean stated, "I think there's this sort of perception that a teenager is this wild and uncontrollable thing in our society. . . . The sort of message I want to give to any educator and any teacher and anybody who is working with young people is to stop thinking of youth simply as young people and recognize that like they're people-fully functioning and fully capable of anything." The beliefs that study participants expressed about young people of color connect to the concept of leading with. Leading with includes adult-youth partnerships where knowledge is co-constructed, young people have power in the relationship, and decisions are made together (McKamey, 2017; Bogad et al., 2018, p.1).

Through a process of base-building (recruiting youth at each school to join the organization and/or the current campaign for change) and action (engaging in campaigns to create change), participants supported youth as they engaged in social justice activism by (a) networking adult and youth supporters, (b) engaging in action, and (c) co-constructing knowledge with young people of color. 
Leading With Youth of Color

\section{Finding 1: Study Participants Networked Adult and Youth Supporters With Young People of Color.}

Through the process of base-building, study participants networked youth and adult supporters with young people of color. To engage in base-building, Nora and Jean, the two adult organizers, established school satellite spaces in city schools, called chapters. Chapters were created at seven out of nine city schools. A chapter was the connection between PFC and the school. To establish a chapter at each school, study participants at PFC first engaged school administration and then selected an individual teacher to be their link or advisor to the school. Study participants were clear with teachers at individual schools about the expectations and the risks of getting involved with the organization. Specifically, Dylan shared, "Youth may be working with you $95 \%$ of the time, but $5 \%$ of the time, young people are going to be mad at your principal and the principal is going to be mad at you ... so you are taking on a little bit of risk here by doing this." Once teachers committed, study participants and young people recruited members to join the chapter.

Study participants understood that they were creating chapters within an educational system that was structured with a top-down hierarchy where young people were often given less power and privilege than adults. Jean stated, "It [the top-down approach] highlights the single story as like, 'this is the narrative we're going to follow.' And when you do a top-down approach, it silences so many voices and it silences people who have a lot to tell you about." Study participants created PFC chapters within the existing schooling structure, so young people of color had opportunities to meet at each school campus. The chapters turned into spaces where meetings were co-led by young people and adults. Young people would attend meetings to discuss the aspects of their schooling experiences they wanted to change in their school community. Youth would also meet at the PFC offices for weekly meetings and to connect with young people from across the district.

Study participants built solidarity within the community by supporting community-building activities such as ice breakers and energizers, as well as, engaging in conversations with youth of color about their schooling experiences. For example, Nora discussed questions she asked youth during chapter meetings, "What I try to do is try to get people to see big picture in terms of outside of their school. So, compare their school to a different school: What are the conditions? Like-what are people experiencing? How is it different? . . What kind of oppression is going on here? Just try to get students to think about experience beyond theirs and compare." Base-building became a vehicle for individuals (youth and adults) to work 
towards change together as a community. The chapters at each school were spaces for young people of color to build relationships, share their experiences, and identify areas in which they wanted to enact change and take action in educational systems.

\section{Finding 2: Study Participants Engaged in Action With Young People of Color.}

Once campaigns were identified, study participants engaged in action with young people of color. Nora shared, "I think any group [of people] who are affected by problems but then can be the leaders to change it, is a good thing." Nora felt that youth of color were directly impacted by educational policies, so they should be the leaders in making change. Action occurred when multiple young people identified a problem or issue with education policy and began to discuss a plan for action. At times members of PFC took action at one school, while at other times they took action across schools. For example, action occurred at one school to improve the quality of school lunches. Members of PFC quickly engaged in one form of action after a young person was allegedly served a moldy lunch in one of the high school cafeterias. A picture of the inedible school lunch was shared on social media by a young person, and the situation at lunch prompted support and action for the PFC chapter at that school. Young people and study participants highlighted the problem that had occurred at lunch on social media and eventually had conversations about making change with members of the community, including adult policy-makers in leadership roles. Jean shared, "basically there was like a small social media storm and people kept sharing this picture and it got around and the company that provides lunch got in a panic and contacted us (study participants) about setting up a meeting with students and how can we improve the school lunch." PFC involvement led to change in the quality of lunch offerings for all young people at that individual school.

Action also occurred across city schools when a citywide issue was identified by young people. PFC engaged in a citywide campaign across different schools through a two-step process: First, participants and youth met with members of their individual schools during the week. Second, the youth delegates from each school met at the PFC offices to discuss the campaign and to distribute tasks across schools. For example, young people felt that the radius for a free bus pass was too far and identified the need to change the radius so more students would be eligible for a bus pass. Nora described her conversations with youth across the city in situations like this, "You [can] go to any lunch table in the city and youth are frustrated by the exact same thing. And that's a huge - those are moments for organizing opportunities." The conversations across city schools led to action which included a "bus pass campaign," where the young people of color asked politicians walk to school with them. Study participants set up meetings through 


\section{Leading With Youth of Color}

their networking channels so young people had the opportunity to engage in this type of action. Politicians and other members of the community walked to school with young people to understand the experiences youth of color navigated getting to school. As a result of the campaign, the bus pass radius was brought down to two miles and over 1800 young people across the city received a bus pass for free.

\section{Finding 3: Study Participants Co-Constructed Knowledge With Young People of Color.}

Young people and study participants engaged in many campaigns to make educational change while learning new knowledge. Throughout the process of base-building and action study participants co-constructed knowledge with young people of color in multiple ways:

First, during summers, PFC hosted summer workshops about systems of oppression and history of resistance to provide foundational knowledge of how people make change in communities. Summer workshop topics included racism—specifically anti-Black racism, capitalism, gender, sexism, and xenophobia.

Second, study participants co-constructed knowledge with youth by finding areas to resist within their schools and helping them identify and facilitate action that would make the most impact. When the needs of each campaign changed, so did the type of action that was engaged; in most cases it was direct action. As outlined in the Table 1, action at PFC included social media (school lunch campaign), inviting politicians to walk the distance from a student's home to school (bus pass campaign), walking out of school and rallying at the statehouse (45 Presidential Election), and engaging in youth-adult policy meetings (standardized test campaign and curriculum campaign).

Within each campaign, youth and study participants identified their areas of strengths and areas in which they needed support. Areas in which youth needed support turned into learning opportunities. Knowledge and skills of engaging in action, specifically direct action, were shared throughout each campaign. For example, for protests, young people were supported as they connected with emergency medical professionals, lawyers and adult allies. Information was collected in documents online and shared by young people, study participants, and community volunteers. Young people were also supported in speech writing and coordinating all of the logistics of the events. Dylan outlined the role adults played in the process: "Youth are in power and can make change. Staff supports, pushes, and joins youth. Everyone teaches each other." 
Leading With Youth of Color

Table 1. Youth Organizing Campaigns at People for Change

\begin{tabular}{|l|l|l|}
\hline Campaign & \multicolumn{1}{|c|}{ Action } & \multicolumn{1}{|c|}{ Result } \\
\hline School lunch campaign & $\begin{array}{l}\text { Social media and youth-adult } \\
\text { policy conversations }\end{array}$ & $\begin{array}{l}\text { Changes in lunch offerings at } \\
\text { one school }\end{array}$ \\
\hline Bus pass campaign & $\begin{array}{l}\text { Youth-adult walk to school and } \\
\text { youth-adult policy conversations }\end{array}$ & $\begin{array}{l}\text { The bus pass radius was } \\
\text { changed, and more young } \\
\text { people received bus passes. }\end{array}$ \\
\hline Standardized testing campaign & $\begin{array}{l}\text { Youth rally and policy } \\
\text { conversations }\end{array}$ & $\begin{array}{l}\text { Standardized testing did not } \\
\text { become a requirement for high } \\
\text { school graduation. }\end{array}$ \\
\hline Curriculum campaign & Youth-adult policy conversations & $\begin{array}{l}\text { Some high schools across the } \\
\text { city offered Ethnic studies. }\end{array}$ \\
\hline $45^{\text {th }}$ presidential election protest & $\begin{array}{l}\text { School walk-out (youth left } \\
\text { school during normal school } \\
\text { hours) and youth rally }\end{array}$ & $\begin{array}{l}\text { Young people had an } \\
\text { opportunity to express their } \\
\text { concerns of the results of the } \\
45^{\text {th }} \text { presidential election. }\end{array}$ \\
\hline
\end{tabular}

\section{Discussion and Implications}

At PFC, the study participants (a) networked adult and youth supporters, (b) engaged in action, and (c) co-constructed knowledge of symptoms and systems of oppression with young people of color. I found that study participants assumed risk in engaging young people of color in social justice activism. Their work was not easy-it was complex and often met with opposition. Study participants reported challenges in their work which included supporting young people in navigating punitive consequences that were given in school, facing media backlash from engagement in action, and balancing many roles and responsibilities. Jean shared some of their experience with opposition, "I think that definitely-you know, when you do activist work like this, it's sort of necessary to have that tension...So, I think that pushback-and it was really like a lot of negativity, just ugly negativity like . . . people wishing harm on students. And-we were flabbergasted and just like, 'Whoa, what?"'

Study participants turned the negativity into fuel to continue engaging in social justice activism with young people of color. Jean also shared, "But you know, like I think it definitely supported our cause and definitely made us like want to do this more...how do you communicate a 


\section{Leading With Youth of Color}

message and how do you poke at the right places ... . regardless of what people are saying about you."

The way in which adults at PFC engaged adolescent youth in social justice activism can be connected to different contexts. First, study participants networked adult and youth supporters with youth of color. The youth-adult dynamic for this process can be connected to Campbell and Erbstein's (2012) principle of "A strategic focus: getting the questions right" (p. 73): identifying who, why, and how you will engage young people in community change. Study participants at PFC worked to build a network of supporters and to build chapters outside of the organization home base. They were intentional in positioning youth as co-leaders as much as possible. Youth of color were viewed as capable and important participants in the process of base-building. This construction of the youth-adult dynamics is in direct contrast with the way in which hierarchies of schooling are set up. Often, young people are positioned as subordinates to adults in hierarchical structures; however, the findings suggests that study participants challenged these traditional models by changing dynamics between youth and adults within chapters nestled in school structures and educational policy meetings.

Second, study participants took action in the community with youth of color. McDaniel (2017) spoke of the importance of youth and adults working together in transforming systems of oppression. Action occurred at individual schools and across the city schools; however, during each campaign, young people of color were supported by study participants and other adult allies. The process of base-building and action often connected to organic idea development and group consensus. Campbell and Erbstein (2012) found it to be important that young people are integrated in decision-making. In this study, I found that through the various forms of action, voices and power of young people of color were not just heard, they were supported.

Third, study participants co-constructed knowledge with youth of color. In traditional K-12 schooling, math and literacy content and skills are emphasized in the curriculum, while the development of critical consciousness and action are not often prioritized (Dialogic \& Critical Pedagogies, 2017; Ginwright \& Cammarota, 2002). At PFC, young people of color were in partnership with adults in understanding making change in educational systems. In connection with the work of Ho et al. (2015) the type of organizing strategies and engagement in action differed with each campaign in which young people of color participated. Campbell and Erbstein (2012) speak of the importance of building coalitions of people with diverse backgrounds, skills, and knowledge and experiences. Study participants made a commitment to support youth of 
color in understanding foundational knowledge of systems of oppression that are not often taught in traditional schooling models. Furthermore, they identified and shared multiple perspectives and strategies of participating in social justice activism with youth of color.

\section{Conclusion}

Historically, young people of color have participated in making educational change (Anyon, 2014), but, the role of how the adults in SJYD spaces support this work is still evolving in the youth development literature and in practice (Ginwright \& Cammarota, 2002; Iwasaki et al., 2014). Study participants shared that they felt that it was not enough to unite youth voice; instead, they believed in establishing support and power behind youth voice. In a final interview Dylan stated, "a seat at the table is not enough, PFC wants to build a powerful youth union, like a teacher's union, to change current power dynamics in policy decision making." Study participants did not lead for or lead against youth of color, they led with young people of color (McKamey, 2017; Bogad et al., 2018, p.1). Youth of color and study participants worked together to make change in educational systems that directly impacted youth from their community. This study is one example of ways in which adult youth workers engage youth of color in social justice activism.

\section{References}

Anyon, J. (2014). Radical possibilities: Public policy, urban education, and a new social movement. Routledge.

Bogad, L, McKamey, C., Restler, V., \& Clemons, R. (2018). Youth Development BA at Rhode Island College [Pamphlet]. Rhode Island College.

Bogdan, R. C., \& Biklen, S. K. (1992). Qualitative research for education: An introduction to theory and methods. Allyn \& Bacon.

Campbell, D. \& Erbstein, N (2012). Engaging youth in community change: three key implementation principles, Community Development, 43(1), 63-79.

https://doi.org/10.1080/15575330.2011.645042

Christens, B.D., \& Kirshner, B. (2011). Taking stock of youth organizing: An interdisciplinary perspective. New Directions for Child and Adolescent Development. 134. http://dx.doi.org/10.1002/cd.309

Dialogic \& Critical Pedagogies: An Interview with Ira Shor. (2017).

https://files.eric.ed.gov/fulltext/EJ1147791.pdf 
Erbstein, N. (2013). Engaging underrepresented youth populations in community youth development: Tapping social capital as a critical resource. New Directions for Youth Development. 138(1) 109124. https://doi.org/10.1002/yd.20061

Freire, P. (2010). Pedagogy of the oppressed. Continuum.

Ginwright, S. (2006). Racial justice through resistance: Important dimensions of youth development for African Americans. National Civic Review, 95(1),41-46. https://doi.org/10.1002/ncr.130

Ginwright, S., Cammarota, J. (2002). New terrain in youth development: The promise of a social justice approach. Social Justice, 29(4), 82-85.

Ginwright, S., \& James, T. (2002). From assets to agents of change: Social justice, organizing, and youth development. New Directions for Youth Development, (96), 27-46. https://doi.org/10.1002/yd.25

Guba, E. G., \& Lincoln, Y. S. (1994). Competing paradigms in qualitative research. In N. K. Denzin \& Y. S. Lincoln (Eds.), Handbook of qualitative research (pp. 105-117). Sage.

Ho, E., Clarke, A., \& Dougherty, I. (2015). Youth-led social change: Topics, engagement types, organizational types, strategies and impacts. Elsevier. 67(2015) 52-62. https://doi.org/10.1016/j.futures.2015.01.006

Iwasaki, Y., Springett, J., Dashora, P., McLaughlin, A. M., McHugh, T. L., \& Youth 4 YEG team. (2014). Youth-guided youth engagement: Participatory action research (PAR) with high risk, marginalized youth. Child and Youth Services. 35, 316-342.

Jones, K. (2006). Relationships matter: A mixed methods evaluation of youth and adults working together as partners. Journal of Youth Development, 2(1), 1-14.

Kirshner, B. (2005). Moral Voices of politically engaged urban youth. Special Issue: Doing the Right Thing: Ethical Development Across Diverse Environments. 2011 (134) 27-41. https://doi.org/10.1002/yd.140

Maxwell, J. A. (2013). Qualitative Research Design (3rd ed). Sage.

McDaniel, M. (2017). Social justice youth work: Actualizing youth rights. Journal of Youth Development, 12(1), 136-148. https://doi.org/10.5195/jyd.2017.488

McKamey, C. (2017): Learning and teaching to care for young people, Child \& Youth Services. https://doi.org/10.1080/0145935X.2017.1297226

Patton, M. Q. (2002). Qualitative research and evaluation methods ( $3^{\text {rd }}$ ed.). Sage.

Permanent Culture Now. (2018). http://www.permanentculturenow.com/what-isactivism/

Richards-Schuster, K., \& Timmermans, R. (2017). Conceptualizing the role of adults within youth-adult partnerships: An example from practice. Children and Youth Services Review, 81, 284-292. https://doi.org/10.1016/j.childyouth.2017.07.023

Rhode Island Education Data Reporting. (2016) RIDE InfoWorks. Retrieved from http://infoworks.ride.ri.gov/district/city 
Journal of Youth Development | http://jyd.pitt.edu/ | Vol. 15 Issue 5 DOI 10.5195/jyd.2020.785 Leading With Youth of Color

U.S. Department of Education. (2016). The state of racial diversity in the education workforce. https://www2.ed.gov/rschstat/eval/highered/racial-diversity/state-racial-diversity-workforce.pdf

Wormser, R. (2002). The rise and fall of Jim Crow. New York: Thirteen WNET. Retrieved from the Library of Congress, https://www.loc.gov/item/2003616267/ 